\title{
NGF Gene
}

National Cancer Institute

\section{Source}

National Cancer Institute. NGF Gene. NCI Thesaurus. Code C105374.

This gene plays a role in the maintenance of sympathetic and sensory neurons. 